\title{
“A transformação do Tabu em totem”:
}

\author{
notas sobre (um)a fórmula antropofágica ${ }^{1}$
}

\begin{abstract}
Alexandre Nodari
Professor de Literatura Brasileira e Teoria Literária da UFPR

Co-fundador do species - núcleo de antropologia especulativa

(https://speciesnae.wordpress.com/)
\end{abstract}

1. A Antropofagia de Oswald de Andrade e seus companheiros poderia ser sintetizada numa série de fórmulas proliferantes, traduzíveis e remissíveis umas às outras, mas cuja inteligibilidade plena depende da análise detida desse seu mecanismo recursivo, desse procedimento que permite a sua disseminação em outras formas, como se a Antropofagia fosse esse constante devir, esse diferir de si, como se ela fosse isomórfica a essa enunciação que não cessa de invocar uma multiplicidade: "Só me interessa o que não é meu", "a posse contra a propriedade", "A vida é devoração", "Tupi or not tupi”, o jogo entre o que "Tínhamos" e aquilo "Contra" o que nos colocamos, etc. Há, porém, uma fórmula que é invocada mais que as outras, seja na Revista de Antropofagia, seja na retomada em termos filosóficos da Antropofagia por Oswald em 1940 e 1950: "a transformação do Tabu em totem". Além disso, ela aparece em uma série de variações que parecem replicar esse procedimento canibal: "a transfiguração do Tabu em totem", "a transformação permanente do Tabu em totem", a "contradição permanente do homem e o seu Tabu", "totemizar os tabus exteriores", "Absorver sempre e diretamente o Tabu”, etc. A hipótese que desenvolveremos aqui é que ela talvez sirva de cifra para a compreensão da Antropofagia, chave de leitura para este modo de enunciação que traz consigo uma

\footnotetext{
1 Uma versão em inglês deste artigo foi publicado em MARQUES, 2014, pp. 409-454. O texto retoma algumas elaborações expostas em um curso de pós-graduação que tive a oportunidade de ministrar em conjunto com Eduardo Viveiros de Castro em 2012, no Museu Nacional (UFRJ). Além disso, também é fruto um diálogo constante sobre o tema com Marcos de Almeida Matos. Agradeço a ambos e também a Flávia Cera, pela leitura das diferentes versões e pelo auxílio com a literatura psicanalítica.
} 
Weltanschauung, visão de mundo como Oswald gostava de caracterizá-la. Já nas páginas iniciais d'A crise da filosofia messiânica, a centralidade da fórmula é ressaltada:

\begin{abstract}
A operação metafísica que se liga ao rito antropofágico é a da transformação do tabu em totem. Do valor oposto, ao valor favorável. A vida é devoração pura. Nesse devorar que ameaça a cada minuto a existência humana, cabe ao homem totemizar o tabu. Que é o tabu senão o intocável, o limite? Enquanto na sua escala axiológica fundamental, o homem do Ocidente elevou as categorias do seu conhecimento até Deus, supremo bem, o primitivo instituiu a sua escala de valores até Deus, supremo mal. Há nisso uma radical oposição de conceitos que dá uma radical oposição de conduta (ANDRADE, 2011a, p. 139).
\end{abstract}

Vejamos, então, mais de perto, no que consiste esta "operação metafísica".

2. Depois de aparecer em três formas diferentes no Manifesto Antropófago, a fórmula ganha um maior desenvolvimento em uma série de textos da chamada "segunda dentição" da Revista de Antropofagia. Um deles, o "antropofagia e cultura”, de 15 de maio de 1929, de autoria de Oswald de Andrade, situa claramente o horizonte intelectual em que ela se insere: "Não há dúvida que o complexo 'Prazer-Desprazer' de Freud domina tudo. Nem nunca santo nenhum desejou o céu senão para gozar, se praticou virtude quis evitar os sofrimentos do inferno em que acreditava. Mas as expressões Tabu e Totem, patrimônio mental do antropófago, intervindo com atualidade na elucidação metapsíquica (...) é que realmente situam a operação da vida. Toda ação humana não passa da transformação do Tabu em Totem - idéia central da Antropofagia”. ${ }^{2}$ Ou seja, apesar de tanto o "totem" quanto o "tabu", instituições distintas provenientes de povos igualmente distantes entre si geograficamente, serem objeto de atenção de muitas obras de antropologia, como The Golden Bough, de James Frazer, livro de cabeceira dos modernistas brasileiros, o ponto de referência oswaldiano é a teoria freudiana. E pelo que podemos inferir da passagem, não se trata apenas de uma invocação do clássico Totem e Tabu, mas a sua reelaboração como substituto do binômio prazer-desprazer. Como sabemos, Freud não opõe o totem ao tabu, mas os conjuga: o totem estaria em íntima relação com os dois tabus primordiais ("aquele que poupa o animal totêmico", e o que proíbe o incesto, instituindo a exogamia, sobre a qual voltaremos). Mas como os tabus e o

2 Os negritos são do autor. Todas as citações não referenciadas em nosso artigo provêm da Revista de Antropofagia (incluindo as do Manifesto Antropófago) e foram extraídas da edição fac-similar referida na bibliografia e tiveram sua ortografia atualizada. 
totemismo teriam se instituído? Freud diz se basear em Darwin para afirmar que a humanidade, em seus primórdios, vivia sob o esquema da "horda paterna", em que um "Pai" dominava todas as mulheres do grupo, incluindo as filhas, e expulsava os filhos homens do grupo. Estes, movidos pelo mesmo desejo de praticar o incesto, "se juntaram, abateram e devoraram o pai, assim terminando com a horda primeva”:

O fato de haverem também devorado o morto não surpreende, tratando-se de canibais. Sem dúvida, o violento pai primevo era o modelo temido e invejado de cada um dos irmãos. No ato de devorá-los eles realizavam a identificação com ele, e cada um apropriava-se da parte de sua força. A refeição totêmica, talvez a primeira festa da humanidade, seria a repetição e a celebração desse ato memorável e criminoso, com o qual teve início tanta coisa: as organizações sociais, as restrições morais, a religião. (...) Eles odiavam o pai, que constituía forte obstáculo a sua necessidade de poder e suas reivindicações sexuais, mas também o amavam e o admiravam. Depois que o eliminaram, satisfizeram seu ódio e concretizaram o desejo de identificação com ele, os impulsos afetuosos até então subjugados tinham de impor-se. Isso ocorreu em forma de arrependimento, surgiu uma consciência de culpa, que aí equivale ao arrependimento sentido em comum. O morto tornou-se mais forte do que havia sido o vivo (...). Aquilo que antes ele impedia com sua existência eles proibiram então a si mesmos (...). Eles revogaram seu ato, declarando ser proibido o assassínio do substituto do pai, o totem, e renunciaram à consequência dele, privando-se das mulheres então liberadas (FREUD, 2012, pp. 217-9).

A hipótese de Freud, assumidamente ficcional, constitui uma das várias versões de um construto muito enraizado no pensamento ocidental: o de que a antropogênese consiste na superação da antropofagia por meio da lei. ${ }^{3}$ Assim, se o tabu que protege o totem se traduz, no campo das relações inter-humanas, em outros dois (a proibição tanto do homicídio quanto da antropofagia), que formam com a vedação do incesto um triunvirato que “dá início ao afastamento da cultura em relação ao estado animal primitivo”, Freud (2010, pp. 45, 46) afirma que, destes três, "apenas o canibalismo parece ser malvisto por todos". Ou seja, nesse esquema, para que a antropogênese se dê, para que o homem passe da natureza à história, é preciso um gesto fundador violento (a antropofagia) e sua imediata interdição - caso contrário, a aliança fraterna formada se desfaz, dando lugar a novas hordas paternas fratricidas e tornando a história cíclica. Para que a sociedade humana se funde, segundo Freud, é preciso um crime inaugural, seguido de sua proibição

\footnotetext{
3 Observe-se que na passagem citada, Freud toma por pressuposto que no princípio era o canibal. Me detive um pouco mais nisso em NODARI, 2013. Uma hipótese que comecei a explorar com Flávia Cera (2013) é a de que a figura da horda ganha em valor heurístico ao ser situada não no começo da história humana, mas em seu final (o "estado de natureza" hobbesiano ou freudiano seria, portanto, uma tentativa ideológica de tomar o efeito do Estado como sua causa).
} 
permanente, i.e., da lei. Ora, ao tomarem a Antropofagia como mote, Oswald e seus companheiros estavam justamente transformando o tabu em totem, tomando aquilo que deve ser banido como bandeira, convertendo o "valor oposto" em "valor favorável". E mais: ao advogarem a "transformação permanente" do tabu em totem, contestavam o modelo evolucionista-progressista que Freud professava, reivindicando um tipo de estado de natureza que não seria temporal e ontologicamente anterior à civilização: "não se deve confundir volta ao estado natural (o que se quer) com volta ao estado primitivo (o que não interessa)", lemos em "A descida antropófaga”, de Oswaldo Costa; do mesmo modo, um texto assinado por Poronominare afirma que a "Antropofagia é simplesmente a ida (não o regresso) ao homem natural". Assim, "estado natural" e "civilização" não seriam estágios sucessivos (ou seja, aos povos canibais "descobertos" durante a Conquista não faltava nada, não faltava um Estado que completasse a hominização), mas configurações político-ontológicas distintas e opostas, "hemisférios culturais", pra usar uma imagem espacial oswaldiana em oposição a uma temporal (a Antropofagia, em uma definição do movimento, é caracterizada como "A reação da paisagem contra o tempo"). Daí a radicalidade de formulações como "Se enganam os que pensam que somos contra somente os abusos da civilização ocidental. Nós somos é contra os usos dela"; e "Todas as nossas reformas, todas as nossas reações costumam ser dentro do bonde da civilização. Precisamos saltar do bonde, precisamos queimar o bonde". Mas de que modo a transformação do tabu em totem permite a passagem da civilização à natureza? E o que significa essa passagem? Como queimar o bonde?

3. Conforme adiantamos, não se pode falar propriamente de transformação do tabu em totem no interior da teoria freudiana. A bem da verdade, parece impossível até mesmo equacionar o que Oswald chama de "totem" e "tabu" com o sentido que Freud dá a esses termos. Talvez a única forma de aproximação entre ambos consista em afirmar que o "tabu" oswaldiano corresponde ao Pai da horda freudiana: só assim se torna possível, no interior da hipótese esboçada em Totem e tabu, conceber uma totemização do tabu, a conversão de uma proibição (no caso, a própria figura do Pai encarnando a proibição) em um totem. Reforça essa hipótese a associação que o movimento antropófago fazia entre a 
transformação do tabu em totem e a devoração: "Absorver sempre e diretamente o Tabu", lemos no "de antropofagia", de 17 de março de 1929, assinado justamente por Freuderico (junção de Freud com Frederico, referência ao prenome de Engels e/ou Nietzsche). Mas, no relato freudiano, não é o tabu que é deglutido e absorvido, e sim o Pai, e, depois, sua forma sublimada, o totem (ou seja, se o tabu, na teoria antropofágica, é outra coisa, o mesmo se pode dizer do totem, porque em nenhum momento Oswald e seus companheiros falam na absorção deste, como Freud fazia). É justamente contra essa devoração sublimada que se volta o aspecto direto da absorção advogada: "O que está errado é a solução contrita, transferida para a absorção na comunhão". Tanto Oswald quanto Freud viam a hóstia como exemplo explícito de uma continuação da antropofagia originária, que, ao mesmo tempo, a nega pelo arrependimento. A diferença entre ambos reside na valoração desse gesto de reforçar o tabu por meio da devoração sublimada: princípio da moralidade para Freud, "baixa antropofagia", "peste dos chamados povos cultos e cristianizados", para Oswald, como lemos no Manifesto. Ou seja, a diferença é que, para este, a devoração sublimada que serve ao tabu não era, como para aquele, um passo necessário, mas uma entre duas possibilidades, e uma má possibilidade, sempre reversível. Trata-se, portanto, de uma diferença de "escala axiológica fundamental". Vejamos mais de perto no que ela consiste.

4. No esquema freudiano, os dois tabus primordiais, a vedação do incesto e a proteção do animal totêmico que opera como substituto do Pai, apesar de interligados, parecem ter uma gênese diferente, com a insinuação de um hiato temporal separando a instituição de cada um. Primeiro viria a exogamia, como solução para evitar o fratricídio na disputa pelo lugar vazio do Pai: "os irmãos não tiveram alternativa, querendo viver juntos, senão (...) instituir a proibição do incesto, com que renunciavam simultaneamente às mulheres que desejavam". Curiosamente, embora sem se deter na questão, Freud associa o período de fraternidade imediatamente posterior à renúncia (ou impossibilidade) de algum dos irmãos "assumir o papel do pai”, o igualitarismo pós-parricídio, a um possível matriarcado, tão advogado por Oswald: "Talvez tenha sido também esta situação que compôs o germe das instituições do direito materno percebidas por Bachofen, até ele ser 
substituído pela ordenação patriarcal". "Já o outro tabu”, continua Freud (2012, pp. 220-1; grifo nosso), como que assinalando a separação entre ambos, o referente ao animal totêmico, "sucedâneo do pai”, pode ser “considerado o primeiro ensaio de uma religião":

pôde-se [com ele] fazer a tentativa de mitigar o vivo sentimento de culpa (...) O sistema totêmico foi, digamos, um contrato com o pai, em que este concedia tudo o que a fantasia da criança podia dele esperar, proteção, cuidado, indulgência, em troca do compromisso de honrar sua vida, ou seja, não repetir contra ele o ato que havia destruído o pai real.

Podemos inferir, já que Freud não é claro quanto a isso, que à deglutição do Pai da horda não sobrevém, de imediato, tanto a exogamia quanto o totemismo, mas aquele (mais ligado ao matriarcado) e depois este (já apontando para o patriarcado), que é o primeiro passo de volta (sublimada) ao Pai. E, de fato, a seguir, Freud (2012, p. 227) relata o caminho de retorno ao Pai, iniciado com o "contrato" totêmico, que passa pela conversão do totem em Deus, "ao qual o clã vinculava então sua origem”, e se estende pela esfera política:

o original igualamento democrático de todos os membros individuais do clã já não podia ser mantido (...) [e] a transformação na atitude perante o pai não se limitou à esfera religiosa, mas estendeu-se coerentemente ao outro aspecto da vida humana influenciado pela eliminação do pai, a organização social. Com a introdução das divindades paternas, a sociedade sem pai converteu-se gradualmente naquela organização de forma patriarcal. A família era uma restauração da antiga horda primeva, e devolvia aos pais uma boa parcela dos seus direitos de antes (FREUD, 2012, pp. 226, 228).

Mas, de novo, na formulação intervém um "talvez" referente a um matriarcado anterior, transitório e de transição: "Não sei indicar em que ponto desta evolução se acham as grandes divindades maternas, que talvez tenham geralmente precedido os deuses-pais" (FREUD, 2012, p. 228). No esquema freudiano, o matriarcado é uma possibilidade histórica, de difícil periodização, mas que antecede a formação patriarcal. Tentemos, mais uma vez, sobrepor à hipótese de Freud o sentido que os antropófagos davam aos termos deste. A dissonância revela-se total: para eles, nenhum desses dois tabus seria, de fato, um tabu. Assim, no texto já mencionado, Freuderico afirma: “Também não tomamos a palavra 'exogamia' no sentido clássico que lhe é dado por Mac-Lennan, Spencer, Gillen, Frazer. (...) Os antropólogos não viram na exogamia senão uma lei tribal, um tabu. [Mas] É uma simples fatalidade. Um fato humano”. A exogamia também é outra coisa (que 
tentaremos decifrar mais adiante). E igualmente, em nenhum momento das formulações dos antropófagos o tabu comparece como um instrumento de proteção do totem. Pelo contrário, são opostos não apenas explicitamente na fórmula sobre a qual estamos nos debruçando, como implicitamente na contraposição entre o totem-animal e o Deushumano realizada por Flávio de Carvalho em A origem animal de Deus. Ali, um corte de cunho narcisista separaria as figuras. Os primeiros deuses, teriomorfos, seriam índice de uma indistinção primordial entre homens e animais, de um igualitarismo transespecífico (ou pré-específico, ou mesmo de uma superioridade animal em relação ao homem, sugere Flávio). A adoção de um Deus à imagem e semelhança do homem estaria ligada a uma quebra dessa continuidade: "Aos poucos, o homem torna-se eminentemente racista repudiando a convivência com os seus companheiros de pasto e, desenvolvendo um sentimento de superioridade, passa a considerar o resto do mundo animal como seres inferiores" (CARVALHO, 1973, p. 73). O especismo seria portanto a primeira forma de racismo: a descontinuidade radical (ontológica) entre os homens e os demais animais implica (ou possibilita) a descontinuidade interna aos homens, ou seja, a hierarquia política. Desse modo, importa sublinhar que, no esquema antropófago, a passagem do totem (deus animal) ao Deus-Pai humano não está pressuposta como necessidade inscrita desde sempre na instituição daquele; ou melhor, não se pode nem mesmo falar de passagem, mas de uma transformação, mais especificamente, poderíamos dizer, uma transformação - inversa - do totem em tabu, do animal cultuado em Pai. "Há nisso uma radical oposição de conceitos que dá uma radical oposição de conduta”, diria Oswald: "o homem do ocidente" toma, em sua "escala axiológica fundamental", "Deus", i.e., o Pai, o Messias, o tabu, como "supremo bem". Ao contrário, "o primitivo instituiu a sua escala de valores até Deus, supremo mal", e sua conduta consistiria em transformá-lo (o tabu) em totem. Se, então, de acordo com o relato de Flávio e Oswald, o Pai da horda primitiva e o Deus-Pai (com seu corolário, o pater familias) são ambos uma única figura, o (mesmo?) tabu, então isso quer dizer que o totem precederia o tabu (o Patriarcado)? De fato, a própria teoria freudiana é tautológica: o patriarcado e a religião, enquanto símbolos da civilização, estão pressupostos no estado de natureza, no Pai da horda primitiva que lhes serve de modelo, e o que os separa deste é uma fase intermediária de negação: o possível 
matriarcado, que talvez não constitua um tempo histórico propriamente dito, mas seja justamente a interrupção da genealogia do Pai, uma espécie de "tempo não-datado" de que fala o Manifesto. Por isso, ainda dentro do esquema (de Freud canibalizado por Oswald, se o Estado (civil, a sociedade) está pressuposto na natureza pré-humana (na horda), o verdadeiro estado de natureza só aparece ali quando se dá o crime inaugural, a devoração do Pai: exatamente o hiato entre a morte do Pai e seu retorno (sublimado). Na medida em que há uma identidade entre o Pai da horda e o pater familias, é impossível determinar o que veio antes: não haveria uma sequência temporal trifásica "Pai primevo > devoração (fraternidade, possível matriarcado) > retorno do Pai", mas uma contraposição dual entre o totem e o tabu. Por isso, o hiato matriarcal não consistiria em algo de duração determinada inscrito em um passado remoto da espécie, mas uma possibilidade sempre aberta. "Absorver sempre e diretamente o Tabu": o "estado natural" não constitui aquilo que é negado para a fundação do Estado, mas aquilo que ativamente permanentemente - se coloca frontalmente (de forma direta) contra o Estado (o tabu, o Pai), aquilo que desfaz o "contrato com deus": a transformação do tabu em totem. Dito tudo isso, a bem da verdade, o tabu dos antropófagos não é propriamente o Pai ("Que sentido teria num matriarcado o complexo de Édipo?”, perguntava-se Oswald (2009, p. 8o)), ou, pelo menos, não enquanto tal. $\mathrm{O}$ tabu, para eles, é o inimigo: não se trata tanto de genealogia, quanto de geografia. Para entender a "idéia central da Antropofagia", precisamos completar o movimento de saída da hipótese freudiana e entrada na "hipótese antropofágica”. Acompanhemos o roteiro que Oswald fornece desse movimento.

5. "Cabe a nós antropófagos fazer a crítica da terminologia freudiana, terminologia que atinge profundamente a questão", afirma Oswald em uma entrevista, na qual resume a série de textos da Revista contendo "as diretivas (...) indicadas para a solução do problema psicológico" (ANDRADE, 2009, pp. 8o, 82). Por isso, na passagem do texto "antropofagia e cultura" que citamos ao começo, está em jogo algo mais que uma substituição de palavras: "Não há dúvida que o complexo 'Prazer-Desprazer' de Freud domina tudo. (...) Mas as expressões Tabu e Totem (...) é que realmente situam a operação da vida”. Se, por um lado, ressalta-se a onipresença da oposição "prazer" e "desprazer", por outro, 
paradoxalmente se aponta a insuficiência desses termos para caracterizar tal onipresença, como se Freud (com quem, afirma Oswald, "A Antropofagia só pode ter ligações estratégicas", pois, apesar de ser "uma das grandes energias do ciclo nascente (...)[,] é apenas o outro lado do catolicismo" (ANDRADE, 2009, p. 80)) tivesse entrevisto a “operação da vida”, e, ao mesmo tempo, a capturasse numa terminologia limitadora. A relação, no interior da teoria freudiana, entre o "princípio do prazer" e a hipótese da horda primitiva é direta (ainda que nem sempre explícita): a ligação pressuposta entre ontogênese e filogênese permite ao psicanalista caracterizar os "mais antigos impulsos instintuais" que ditam o prazer como pertencendo à fase "oral" ou "canibal", regida apenas por apenas dois procedimentos - "Quero comer isso" ou "Quero cuspir isso" (FREUD, 2011, p. 278). Nessa fase do indivíduo e/ou da espécie, não haveria "a oposição entre subjetivo e objetivo", nem mesmo aquela entre dentro e fora, mas tão somente a que distingue o prazeroso do desprazeroso: "O Eu-de-prazer original quer introjetar tudo que e bom e excluir tudo o que é mau (...)[;] o que é mau e o que é forasteiro, que se acha de fora, são idênticos inicialmente” (FREUD, 2011, p. 278). Os irmãos da horda primitiva, poderíamos dizer, regidos unicamente pelo princípio do prazer, buscariam o prazer de dois modos: matando o Pai, eliminariam aquilo que impede o acesso às fêmeas do grupo; devorando-o, também se identificariam com ele, visando assumir a sua posição bendita dentre as mulheres. Mas aí, como vimos, interviria, ou surgiria, a consciência: se (cada) um dos irmãos passasse a ocupar, de fato (e não só imaginariamente) o lugar do Pai, um novo parricídio se seguiria, de modo que a única opção viável seria a renúncia às mulheres do grupo. A essa abdicação que a instalação do totemismo e o estabelecimento de tabus simbolizariam, o psicanalista chama de "princípio de realidade": "Por influência dos instintos de autoconservação do Eu", o princípio do prazer "é substituído pelo princípio da realidade, que, sem abandonar a intenção de obter afinal o prazer, exige e consegue o adiamento da satisfação, a renúncia a várias possibilidades desta e a temporária aceitação do desprazer, num longo rodeio para chegar ao prazer" (FREUD, 2010b, p. 165). Assim, o princípio da realidade seria o responsável por estabelecer as distinções entre interno e externo, subjetivo e objetivo, ou seja, seria uma condição para o surgimento do Eu por meio do discernimento de um pólo oposto a este, a saber, o 
mundo: trata-se de uma "questão de exterior e interior. O não real, apenas representado, subjetivo, está apenas dentro; o outro, o real, também se acha fora (...) A experiência ensinou que é importante não apenas que uma coisa (...) possua a característica 'boa', isto é, mereça o acolhimento no Eu, mas que também se ache no mundo exterior" (FREUD, 2011, p. 279). O “aparelho psíquico", resume Freud (2011, pp. 250-1), "é decomposto num Eu voltado para o mundo externo e provido de consciência e num Id inconsciente, dominado por suas necessidades instintuais", ou seja, num Eu consciente regido pelo princípio da realidade e um Id regido pelo princípio do prazer - de um lado, cultura (totens e tabus); de outro, natureza (horda). Esta decomposição atingiria até mesmo os sentidos, na medida em que o psicanalista parece ver neles duas funções distintas: a primeira serviria ao princípio do prazer, introjetando o que é bom, primordialmente pelo paladar (a oposição comer/cuspir), o qual, porém, não deve ser entendido como um sentido singular, mas um modo de funcionamento de todos eles (pensemos em expressões do tipo "comer com os olhos"); já a segunda operaria como instrumento do princípio oposto, na forma de um "tatear" (e não por acaso, Freud situa o Eu na pele ${ }^{4}$ em que "o Eu envia (...) pequenas quantidades de investimento ao sistema perceptivo, mediante as quais prova os estímulos externos, retraindo-se novamente após cada um desses avanços tateantes" (FREUD, 2001, pp. 280, 281) - ou seja, a função tátil dos sentidos não visaria o toque, mas uma tomada de distância, a medição das distâncias, para estabelecer a fronteira entre dentro e fora. "Mas", para usar uma pergunta do Manifesto, "que temos nós com isso?"

6. “Todo nosso julgamento obedece ao critério biológico. A adjetivação antropofágica é apenas o desenvolvimento da constatação do que é favorável e do que é desfavorável ao homem biologicamente considerado. Ao que é favorável chamaremos bom, justo, higiênico, gostoso. Ao que é desfavorável chamaremos perigoso, besta, etc.” Essa

\footnotetext{
4 "O Eu é sobretudo corporal, não é apenas uma entidade superficial, mas ele mesmo a projeção de uma superfície. (...) Ou seja, o Eu deriva, em última instância, das sensações corporais, principalmente daquelas oriundas da superfície do corpo. Pode ser visto, assim, como uma projeção mental da superfície do corpo, além de representar (...) as superfícies do aparelho psíquico” (FREUD, 2011, p. 32)

5 Poderíamos concluir, assim, que a noção kantiana de gosto estético, o "prazer desinteressado", seria a dominação do paladar pelo princípio de realidade?
} 
passagem do texto de Freuderico, como tantas outras da Revista, parece, à primeira vista, apenas advogar a preponderância de algo semelhante ao princípio do prazer freudiano, o livre fluir dos impulsos instintuais. Assim, de modo semelhante, lemos em "o kangeruku do dogma”, assinado por Tamadaré: "A revolta cósmica da criatura contra o criador é uma vitória do instinto sobre 'as faculdades da alma', coisa abstrata em cuja hipóstase apoia a escamoteação dogmática. E todo o velho edifício da psicologia clássica”. Todavia, se assim fosse, os antropófagos não precisariam apontar a insuficiência terminológica do "Complexo Prazer-Desprazer", mas apenas negar o princípio da realidade, o que absolutamente não ocorre, na medida em que justamente os nomes das instituições que marcariam simbolicamente o início de seu funcionamento (o totem e o tabu) são invocados para substituir o vocabulário do Id. Por isso, se atentamos bem para o que diz Freuderico, o "critério biológico" que preside ao julgamento canibal não se baseia no prazer nem na (consciência) moral, nem no (puro) corpo nem na alma: o "sistema métrico antropofágico” tem como valores básicos não o prazeroso e o desprazeroso, e sim o "favorável" e o "desfavorável", esse associado ao totem, aquele, ao tabu - valores dos quais decorrem não só o prazer ("gostoso") como também a moral ("justo"). E mais: se a Antropofagia “[dá] ao homem”, como lemos no "de antropofagia” assinado por JapyMirim, “o sentido verdadeiro da vida, cujo segredo está - o que os sábios ignoram - na transformação do tabu em totem”, ou seja, do "valor oposto" em "valor favorável”, então estamos muito distantes da "fase canibal" freudiana, já que nesta se dá apenas a incorporação do que é bom, e a expulsão do que é mau (jamais a absorção deste para sua conversão naquele). Como entender, então, a "escala termométrica do instinto antropofágico" de que fala o Manifesto? Voltemos à entrevista de Oswald sobre "a psicologia antropofágica”. Ali, ao propor a “crítica da terminologia freudiana”, ele afirma: "O maior dos absurdos é por exemplo chamar de inconsciente a parte mais iluminada pela consciência do homem: o sexo e o estômago. Eu chamo a isso de 'consciente antropofágico'. O outro, o resultado sempre flexível da luta com a resistência exterior, transformado em norma estratégica, chamar-se-á o 'consciente ético”' (ANDRADE, 2009, p. 80). Aqui, estamos diante de um ataque direto à série de oposições freudianas que acabamos de resumir: a consciência não seria algo que surge (bio- ou ontologicamente) 
depois da vida instintiva, ou melhor, essa separação não faria sentido algum. "O homem sabe o que deve comer" (ANDRADE, 2009, p. 66), resume Oswald em outra entrevista: o desejo e o instinto são consciência, assim como a consciência é instinto e desejo. Monismo, portanto, e em mais de um sentido. Pois não é só a humanidade que sabe o que comer, afinal, "o homem é [apenas] um anel na eterna cadeia da devoração": ao chamar de conscientes as duas operações básicas da vida (aquilo que uma visão redutora chama de "alimentação" e "reprodução"6), Oswald estava igualando vida e consciência (não por acaso, ao retomar a entrevista em um texto posterior, ele falará não mais em "parte mais iluminada pela consciência do homem", mas "parte mais iluminada do ser" - ANDRADE, 2008, p. 326; grifos nossos). Por isso, essas operações constituem o "consciente antropofágico", como se tudo que comêssemos (no duplo sentido, ou seja, tudo com que nos relacionamos) fosse humano, isto é, em certo sentido, um semelhante (vivo e consciente): "O espírito recusa-se a conceber o espírito sem o corpo. $\mathrm{O}$ antropomorfismo". Antropomorfismo, mas que por essa razão questiona justamente o privilégio do humano em sentido estrito. Portanto, "a elucidação de todos os erros dualistas e a Crítica do Espírito realizada definitivamente pela Antropofagia" não vai no sentido de um determinismo biológico (expressão que só faz sentido numa visão dualista) que apregoaria uma struggle of life regida pelo instinto apolítico do indivíduo ou da espécie; antes, aponta para a politicidade de toda relação natural (se tudo é humano, tudo é político), e, com ela, a crítica da noção mesma de indivíduo - ecologia, poderíamos dizer.

7. "Alma para nós não é a divisão tripartida de Platão, nem a pessoa empírica, nem o indivíduo físico-psíquico. É como disse um antropófago, um aparelho mnemônico-

\footnotetext{
$6 \quad$ Em uma conversa rememorada por Milton Carneiro, Oswald afirmava: "a Antropofagia que prego tem sólido fundamento científico: o 'pansexualismo' do Segismundo Freud”. O jovem Carneiro, à época estudante de Medicina, não concordou e retrucou: "Acho que Segismundo exagera o valor do sexo quando faz dele o fundamento exclusivo de toda a vida psíquica, normal e patológica do homem. E olhe aqui, dr. Oswald: exagero por exagero, pan por pan, prefiro o pan muito mais inocente, a que chamo 'pantrofismo'. Proponho que o 'pansexualismo' (tudo é sexo, na vida) freudiano seja substituído pelo meu 'pantrofismo' (tudo na vida é nutrição; a vida é a nutrição)". Oswald concordou: "Tem razão. (...) vou modificar inteiramente o embasamento científico da doutrina antropofágica. (...) 'Pansexualismo' é coisa batida e exagerada, ao passo que o tal 'pantrofismo', também coisa exagerada (...), goza desta enorme vantagem: ninguém sabe o que é" (ANDRADE, 2008, pp. 287-8). Pansexualismo $e$ pantrofismo: a vida é sexo e devoração, duas formas de relação com a alteridade.
} 
telepático encaixado numa cabina física cujo raio de ação não atinge mais que um simples horizonte de pedrada. A generalização absurda dos fatos psicológicos é o que foi 'alma'. Pura abstração. Atoleiro". Essa divertidíssima e bizarra definição, tomada por Tamandaré do texto "antropofagia e cultura", nega peremptoriamente qualquer divisão entre funções altas e baixas da alma, postulando novamente um monismo, mas, ao mesmo tempo, ataca toda individuação subjetiva, como se designasse um paradoxal eu que não se restringe a si mesmo ("telepatia"), mas que nem por isso se confunde com os outros eus ("cabine física"). Mas vejamos mais de perto os contextos em que essa definição aparece. Em primeiro lugar, ela se insere no interior de uma revisão crítica (e sumária) da psicologia da época (Behaviour, Psicanálise, Gestalt), em que as diversas oposições propostas por essas correntes são descritas como "Finalismo sem finalidade":

\begin{abstract}
da psicanálise - prazer - desprazer; afetivo, da Gestalt ${ }^{7}$; simpático - Antagônico, de Scheller. No fundo, Antropofagia, só Antropofagia, isto é, Finalismo com Finalidade (...) Os gestaltistas não examinaram toda essa redução em que o homem reside com antenas possantes e que eu chamo de Cabina Ptolomaica. Do finalismo físico-emocional (Freud, Watson, Köhler, Koffka, Russel), é preciso dar o grande salto. Passar ao finalismo digestivo. Antropofagia.
\end{abstract}

Ou seja, se a psicologia podia talvez explicar a causa última do comportamento humano (as oposições pelas quais este se guia, o finalismo), falhava em apontar a sua destinação, a sua intenção (a sua finalidade - do prazer, por ex.). E aqui intervém a telepatia, as “antenas possantes": a finalidade (telos) é sentir (pathos), mas sentir fora de si, o exterior (portanto, ao mesmo tempo tanto princípio do prazer - sentir - quanto princípio da realidade - exterioridade), sentir o outro, sentir com o outro, o que implica, obviamente, um sair de si. Daí a afirmação de que é "Tudo cósmico e exterior", associado à eliminação do "curto circuito do subjetivismo": como tudo, mesmo o eu é exterior a si mesmo, ele é corporalmente telepático, tem "antenas possantes". Se estamos certos, o que estava em jogo era a preponderância da alteridade sobre a identidade, da relação com o outro sobre a afirmação do sujeito (lembremos, como contraposição, do modelo freudiano do infante regido unicamente pelo princípio do prazer, que só se interessa por ele mesmo). Mas essa

\footnotetext{
$7 \quad$ Aqui, é provável que Oswald tivesse em mente a força que os gestaltistas atribuíam aos processos afetivos na cognição. Veja-se, por exemplo, essa afirmação de Koffka (1924, p. 102; trad. nossa): "não existe um hiato intransponível separando os processos afetivo e cognitivo".
} 
finalidade não é transcendente, não chega a uma comunhão, pois o "horizonte telepático funciona, porém, numa cabina de sistema ptolomaico, presa às convicções horizontais e estáticas da terra. Capaz somente de atingir um horizonte de pedrada". E aqui transparece o segundo eixo contextual em que a menção à telepatia aparece, enquanto contraposição à metafísica: "Longe de qualquer metafísica, existe a conduta telepática". Sentir e pensar à distância (com o outro) não é algo que está além do corpo. Mas como funciona tal telepatia, ao "que se pode reduzir o drama que a pesquisa ocidental exacerba agora"? A resposta dos antropófagos será: "Introversão e Exogamia".

8. Uma das duas principais definições de introversão aparece em "antropofagia e cultura": "Introversão. Duas operações básicas: generalizar e abstrair. Totemizar o exterior. E logo criar o Tabu (Gestalt) para uso exogâmico. A conquista. O tacape." Como entendê-la? Trataria-se de um processo único (generalizar e abstrair 0 totemizar 0 criar o tabu 0 exogamia)? Ou "totemizar" e "criar o tabu" corresponderiam as duas "operações básicas", "generalizar" e "abstrair", respectivamente (o que é reforçado pela repetição da conjunção "e" ao longo da formulação)? A mesma dúvida paira quando lemos a outra definição, provinda do texto de Freuderico: "Por um mecanismo que chamamos 'Mecanismo da introversão', o homem é o animal que pluraliza. Pluraliza e inventa o conceito. Sobre o conceito constrói e legisla. Cria o tabu." Trataria-se de uma progressão que vai da introversão à criação do tabu? Ou então estaríamos diante de uma polaridade marcada pela conjunção "e", cujos nortes seriam, de um lado, a introversão (agrupando a pluralização e a construção sobre o conceito), e de outro, a criação do tabu (que atrairia a legislação e a invenção do conceito)? Provavelmente, as duas coisas ao mesmo tempo: um único processo que engloba tanto a introversão quanto a criação do tabu, mas polarizado, de um lado, por estes termos inicial e final - quanto mais pro início da definição (quanto mais do lado esquerdo), mais ligado à introversão, quanto mais por final dela (do lado direito), mais ligado à criação do tabu -, e, de outro, internamente: dentro de cada frase, o primeiro termo tenderia à introversão (pluralizar, construir), e o segundo, à criação do tabu (invenção do conceito e legislação), como se cada operação ligada à introversão tivesse, sempre, duas faces. Adentremos as duas definições para tentar compreender 
melhor. Nelas, a introversão parece designar uma operação de diferenciação e agrupamento (pluralização e generalização) do mundo, uma forma de conhecimento, de ordenação não científica (neutro), mas sim valorativa, mais especificamente, (o)posicional. E se, no contexto, "generalizar" aparece relacionada a "Totemizar o exterior", não assombra. Já no início do verbete clássico para a Encyclopcedia Britannica, Frazer distinguia o fetiche do totem pelo caráter genérico desse: "Distinto de um fetiche, um totem nunca é um indivíduo isolado, mas sempre uma série de objetos”. O totem, assim, era definido como "uma série de objetos materiais que um selvagem encara com um respeito supersticioso, acreditando haver entre ele e cada membro da série uma relação íntima e muito especial", e tal "relação especial" era caracterizada pelos antropófagos com o termo freudiano "identificação": "aceitar o ponto de vista do primitivo que se identificava com o totem”. O que talvez seja digno de nota é a compreensão do procedimento totêmico como uma forma de conhecimento, uma operação psicológica básica que associa classificação e identificação, divisão e oposição, sensível e inteligível. O conhecimento sensível canibal não tem como horizonte a ontologia, o ser das coisas, mas o caráter relacional delas, como se vê na passagem seguinte:

Ao que é favorável chamaremos bom, justo, higiênico, gostoso. Ao que é desfavorável chamaremos perigoso, besta, etc. É a única introversão que nos permitimos. O índio não tinha o verbo ser. Daí ter escapado ao perigo metafísico que todos os dias faz do homem paleolítico um cristão de chupeta, um maometano, um budista, enfim um animal moralizado. Um sabiozinho carregado de doenças.

Mas a totemização não designa o processo inteiro de introversão; antes, apenas a parte relativa ao pólo favorável: "Quando o homem transforma o tabu em totem, não o faz por atividade mental, nem por uma questão de fé (ignorância da razão suficiente) mas por necessidade de absorver o ambiente atraindo-se forças favoráveis”. Para dizê-lo de outro modo: o totem é o estabelecimento de aliados externos, de forças favoráveis do mundo. Mas como entender que esse mesmo processo implicasse (ou levasse) também à criação do tabu? 
9. É aqui que as referências à Gestalt-Theorie na elaboração antropofágica se iluminam e podem iluminar a nossa questão. Em um trecho de suas memórias, Oswald a associa justamente ao procedimento psicológico de generalização pelo qual apreendemos a realidade, ou seja, algo muito próximo à introversão: "A verdade é sempre a realidade interpretada, acomodada a um fim construtivo e pedagógico, é a Gestalt que suprime a dispersão do detalhe e a inutilidade do efêmero" (ANDRADE, 2002, p. 54). Provavelmente, o contato de Oswald, direto ou indireto, tenha sido com a obra de Köhler (1929) e Koffka (ambos mencionados por ele em "antropofagia e cultura”), que à época se esforçavam para divulgar a Gestalt nos Estados Unidos. Como se sabe, a máxima gestaltista é a de que o todo é outro (diferente) que a soma de suas partes; o que importa na percepção, bem como nos processos cognitivos, não são os elementos isolados, mas as relações que travam entre si, ou seja, as estruturas que os constituem: "Estruturas (...) são reações muito elementares, que fenomenalmente não são compostas de elementos constituintes, sendo o que são devido a seu 'papel-de-membros', seu lugar no todo; sua natureza essencial sendo derivada do todo de que são membros" (KOFFKA, 1922, p. 543). Ou seja, a Gestalt buscava compreender o que Koffka (1922, p. 541) chamava de "experiência integral indivisa": "Indivisa não significa uniforme, pois uma experiência pode ser articulada e envolver uma imensa riqueza de detalhes, sem que isso faça dela uma soma de experiências [divididas]". Todavia, a dificuldade em entender sua apropriação pelos antropófagos se deve não apenas a estes a misturarem com a terminologia freudiana totalmente ressignificada (como estamos vendo), mas especialmente por uma aparente contradição quando da sua invocação nessa mistura. Por um lado, nos textos da Revista, ela aparece sempre associada à criação de tabus: "criar o Tabu (Gestalt) para uso exogâmico”; "Gestalt. Tabu. A passagem sutílima, vitoriosa, antropofágica da 'coisa em si' ao imperativo categórico". Se a última citação parece remeter à passagem do elemento isolado (“coisa em si”) à sua posição em uma estrutura (“imperativo categórico"), e a anterior segue imediatamente à operação de “Totemizar o exterior", parecendo formar uma estrutura com ele, não resta claro por que é o Tabu que é associado diretamente a Gestalt. E aqui entra o aspecto contraditório, pois, por outro lado, na capital entrevista de Oswald sobre o tema, é à totemização que ela se liga: 
"Unificando numa figura (Gestalt) o universo fragmentário, totemizamos - produzindo ao mesmo tempo o novo tabu com que partimos à aventura exterior da conquista (exogamia)" (ANDRADE, 2009, p. 82). Talvez essa seja a única referência a Gestalt que faça uso mais explícito do próprio vocabulário dela, o que a torna mais decifrável. Aqui aparecem, de uma vez, dois aspectos gestaltistas. De um lado, a totalização da experiência, a formação de uma estrutura (unificação); de outro, a relação entre figura e fundo, central nas elaborações da Gestalt: a totemização seria, desse modo, a conversão, em uma figura unitária, de um fundo, o "universo fragmentário, resultando, assim, em uma "experiência integral indivisa". Consequentemente (e dissipando a aparente contradição assinalada), já que a figura parece ser associada ao totem, poderíamos associar o tabu ao fundo - na terminologia antropófaga, o "ambiente": "A autoridade exterior, ou melhor, a interdição climatérica no mais largo sentido, é o tabu. Que é antropofagia? A absorção do ambiente. A transformação do Tabu em totem.” Essa relação se reforça pela passagem seguinte da entrevista: "Um dos fenômenos de permanência psicológica que mais de perto acompanham a ação humana é a criação do tabu, elemento de função fixa na transformação do eterno presente. O seu caráter é sacro: o direito, a arte e a religião" (ANDRADE, 2009, p. 82; grifo nosso). Pois era justamente um caráter de fixidez que os gestaltistas atribuíam ao "fundo": além de variar menos (ou de suas variações serem menos perceptíveis), ele serve como limite, como contorno à figura. ${ }^{8}$ Talvez essa associação totem-figura e tabu-fundo permita compreender melhor o motivo de Oswald afirmar que "Na totemização desses valores [os tabus: arte, direito, religião] todos os dias consiste a vida individual e social, que por sua vez renova os tabus, numa permanente e, graças a Hegel, insolúvel contradição" (ANDRADE, 2009, p. 83). A totemização produziria "ao mesmo tempo o novo tabu", ou seja, não recairia em uma síntese, não constituiria um movimento de superação progressista, porque não há figura sem fundo. E, além disso, a inversão figura-fundo altera a ambos conjuntamente mudando a perspectiva (a "atitude", no vocabulário da Gestalt), muda também o objeto (no caso, o mundo, o "universo fragmentário"). Talvez fosse isso que Oswald tivesse em

\footnotetext{
8 Os experimentos de inversão com desenhos e diagramas baseavam-se nisso: um quadrado preto (figura) com um buraco branco no meio (fundo) pode ser, inversamente, um bola branca (figura) circundada por um pano preto (fundo).
} 
mente ao falar da "potência de transformador gestaltista" do "aparelho mnemônicotelepático", com a ressalva de que esse desejo de totalização da experiência é sempre limitado, pois "encaixada numa cabina física cujo raio de ação não atinge mais que um simples horizonte de pedrada": a transformação é sempre e insuperavelmente limitada. Seja como for, mesmo que o tabu dos antropófagos não designe exatamente o fundo de uma relação figura-fundo, não deixa de haver uma semelhança entre o caráter fixo do tabu e a importância das “quantidades invariáveis" para a Gestalt: toda transformação de um campo gestaltista se dá a partir da fixação de uma invariante a partir da qual o campo é reorganizado. ${ }^{9}$ E a invariante (o tabu, o fundo) da Gestalt canibal atendia pelo nome de inimigo.

10. De acordo com a etimologia mais difundida (e mencionada em quase todos os trabalhos sobre o assunto), a palavra polinésia "tabu" derivaria da junção de ta (marcar) e pu (advérbio de intensidade), designando, desse modo, algo marcado intensamente. Mas o que o "thrice mysterious Taboo" (para usar a expressão de um literato ${ }^{10}$ ) marcaria? A antropologia vitoriana, acompanhada por Freud, e gestada numa sociedade ela mesma repleta de evitações rituais, respondeu se tratar de uma espécie de sobre-naturalidade primitiva (análoga ao sacer romano) que confundia o sagrado e o impuro - e cuja diferenciação resultaria, por um lado, nas idéias religiosas e morais, e por outro, nas superstições que seriam a sobrevivência da confusão arcaica. Todavia, como mostrou Franz Steiner na sua magistral monografia sobre o tema, a suposta ambivalência era uma projeção dos "observadores” sobre aqueles que "observavam”: vendo no tabu duas coisas distintas e contraditórias, preferiram, em vez de elaborar uma explicação que prescindisse do paradoxo, pressupor que os "primitivos" as confundissem, ou que houvesse uma zona primordial em que elas ainda não se tivessem sido diferenciadas (essa zona sendo

9 Cf. KOFFKA, 1936, pp. 218ss. Por exemplo: segundo Wertheimer, a teoria da relatividade de Einstein teria reorganizado (transformado) o campo gestáltico da física por meio da introdução da velocidade da luz como quantidade invariante, o que permitiu estabelecer relações antes impensadas entre quantidades como espaço e o tempo. Cf. Miller, 1975.

10 Estamos nos referindo a Herman Melville (1846, p. 227). É curioso o contexto em que a expressão comparece: "In truth, the Typees, so far as their actions evince, submitted to no laws human or divine always excepting the thrice mysterious Taboo". Um dupla exceção da ausência de leis, o exato inverso do modo como Giorgio Agamben (2002, p. 90) caracterizou a sacratio romana: "dupla exceção, tanto do ius humanum quanta do ius divinum, tanto do âmbito religioso quanta do profano”. 
tautologicamente definida pela indiferenciação daquilo que irá se distinguir). Se há algo que o conceito de tabu indica, afirma Steiner (1967, p. 147), é o perigo: o tabu marca os "pontos perigosos" (dangerous spots), ele consiste na "localização institucional do perigo, tanto pela especificação do perigoso quanto pela proteção da sociedade em relação às pessoas em perigo e, portanto, perigosas". Perigo não designa apenas a possibilidade de destruição, adverte o autor, remetendo ao sentido arcaico do inglês "danger", que indica poder, jurisdição, domínio (a palavra deriva do latim dominium), em suma, potência: "Enfrentar o perigo é enfrentar outro poder (To face danger is to face another power)" (STEINER, 1967, p. 146). E esses perigos, esses poderes que o tabu marcaria, residiriam especialmente naquelas zonas limiares, de passagem entre o dentro e fora, como que demarcando limites. É por isso que, segundo Steiner (1967, p. 116), se na "transformação, no devir, (...) o estágio anterior à transformação e aquele posterior a ela são socialmente reconhecidos, salvaguardados e protegidos",

\begin{abstract}
a passagem sobre a fronteira em si é, contudo, ausente de tais salvaguardas e se situa em um domínio de perigo. Ao passar através (...) desses perigos, abstenções rituais são observadas, e nesse contexto descobre-se subitamente que o maior número de tabus de fato diz respeito às várias delimitações de nossos domínios e fronteiras (...). Os tabus dizem respeito à passagem de coisas para dentro e fora do corpo; eles resguardam os orifícios do corpo. Os tabus controlam mudanças como a passagem de um ambiente mais familiar para um mais estranho ou estrangeiro. Um aspecto do tabu indubitavelmente consiste em prover um idioma para a descrição de tudo que importa em termos (...) de transgressão; isto é, de passagem de dentro para fora ou de fora para dentro da competência (...) do indivíduo.
\end{abstract}

É evidente que Oswald e seus companheiros não conheciam a "sociologia do perigo" de que fala Steiner, e até mesmo rejeitassem um tanto explicitamente a literatura antropológica sobre o tabu, o totem e a exogamia, preferindo, como vimos, abordá-los apenas indiretamente pela crítica à terminologia freudiana. Porém, também é verdade que eles associavam o tabu justamente aos limites e às potências externas: "Que é o tabu senão o intocável, o limite?"; "O limite, o tabu dos primitivos. A adversidade metafísica”; o "limite adverso"; "A autoridade exterior, ou melhor, a interdição climatérica no mais largo sentido, é o tabu." É por isso que a antropofagia ritual tupi apresentava-se como exemplo dessa "operação metafísica", pois se tratava de devorar justamente o inimigo, o adversário poderoso: 


\begin{abstract}
a Antropofagia como comunhão do valor adverso. Pois é evidentemente primordial que se restaure o sentido de comunhão do inimigo valoroso no ato antropofágico. $O$ índio não devorava por gula e sim num ato simbólico e mágico onde reside toda a sua compreensão da vida e do homem. Trata-se apenas da transformação do tabu em totem, isto é, do limite e da negação em elemento favorável.
\end{abstract}

Se voltamos agora à reformulação da terminologia freudiana proposta pelos antropófagos, talvez possamos entender melhor o que estava em jogo: ao preferirem a oposição entre totem e tabu (este compreendido como o inimigo) para situar a "operação da vida”, eles estavam optando por um modelo contraposto àquele narcisista do princípio do prazer. A vida e o sentido derivariam de uma oposição desde sempre política (isto é, que implica a diferença, a alteridade, o mundo, o externo, etc.). Isso pode ser reformulado em ainda outra dimensão: os antropófagos, em um gesto que negava o relato (como o freudiano) que situa a célula familiar como origem da pólis e da civilização (que cresceria concêntrica e acumulativamente a partir do Pai - um super Eu - em direção à autoridade política e a Deus), não associavam o tabu ao pai, mas ao inimigo, optando por um modelo oposicional, de modo que a própria figura de Deus não representaria um Pai absoluto, mas o inimigo máximo ("Deus é o elemento contrário"), de onde viria o "conceito do primitivo sobre Deus, que é afinal o tabu, o limite, o contra": "A religião do índio era por isso o inimigo forte que ele devorava. Sempre a absorção do tabu. E a sua transformação em totem. A chave do problema humano.” Talvez aí resida o sentido do "ateísmo com Deus" propalado por Oswald: "A luta entre o que se chamaria Incriado e a Criatura ilustrada pela contradição permanente do homem e o seu Tabu. (...) Antropofagia. Absorção do inimigo sacro. Para transformá-lo em totem. A humana aventura. A terrena finalidade." Deus não é uma figura com quem se assina um contrato, mas sim com quem se trava uma guerra, ou então com quem se contrai alianças, isto é, que se totemiza, com quem se faz contato.

11. Justamente porque indica uma potência estranha, porque demarca os limites, o tabu não deve ser tocado - sob risco do perigo se libertar, contagiar: "o tabu se transmitia como que por infecção a tudo que a pessoa ou coisa tabu tocasse”, diz Frazer em seu 
verbete sobre o instituto polinésio. É esse aspecto que permite a Freud (2012, pp. 54-5) uma associação com a neurose obsessiva:

\begin{abstract}
Como no tabu, a interdição principal e núcleo da neurose é a de contato, daí o nome 'medo do toque', délire de toucher. A proibição se estende não só ao contato direto com o corpo, abrangendo o que designamos, em linguagem figurada, com a expressão 'entrar em contato'. Tudo que dirige os pensamentos para a coisa proibida, que produz um contato em pensamento com ela, é proibido tanto quanto o contato físico direto. A mesma abrangência é encontrada no tabu.
\end{abstract}

Arrisquemos agora uma síntese selvagem para tentar resolver uma questão esboçada mais acima: 1) o tabu designa uma potência exterior, uma exterioridade potente, um limite que não deve ser tocado, sob pena de liberar um perigo; 2) o tato, na teoria freudiana, é algo como um modelo de funcionamento do princípio de realidade, servindo para sentir o que é externo, em contraposição ao paladar, modelo do princípio do prazer. Ora, se estamos corretos quanto ao monismo proposto pelos antropófagos, então essa cisão dualista entre tocar e devorar cai por terra: a exterioridade não é algo que tateamos à distância, mas que experimentamos - “o tatear, como contato, é já o prenúncio da devoração”, para usar uma formulação de Elias Canetti (1995, p. 202). De fato, “contato” era um termo essencial do vocabulário antropofágico: “O contato com o Brasil Caraíba”, o "contato com a terra”, o “contato com o título morto", etc. E se a exterioridade está repleta de potências e perigos, o tato canibal não consiste, como o freudiano, em um mecanismo de mapeamento dos perigos externos para sua evitação, mas sim de tomada de contato com ele. $\mathrm{O}$ tabu não deve ser evitado, deve ser devorado, absorvido diretamente: é uma guia para ação (uma "norma estratégica") - "Viver é totemizar ou violar o tabu"; "O desejo de absorver traz a infração do tabu”. E a esse contato com a exterioridade, Oswald e seus companheiros chamaram de "exogamia”: “exogamia', essência do homem na busca da aventura exterior que é toda a vida". A exogamia, como vimos, não era concebida como uma instituição social; não se trataria de uma regulação do parentesco, o casar-fora, mas do imperativo de se relacionar com o fora (casar com o fora, por assim dizer). E esta relação comportaria sempre um risco, comporta um contato com o perigo: "Exogamia é a aventura exterior. O homem-tempo depois de Einstein é feito de momentos que são sínteses biológicas. Para a formação de cada um desses momentos ele arrisca o pelo numa aventura exogâmica. Realizada a síntese, ele a integra, como a ameba integra o alimento e busca outra 
aventura exogâmica". Ou seja, a exogamia produziria o des-centramento do sujeito que busca sua consistência própria, o contato, sempre arriscado, com o fora, o acontecimento: "Exogamia. Totalidade da humana aventura. O que a humanidade quer é pretexto para viajar. (...) Contra o homem econômico de Marx - a realidade opõe o antropófago turista, o homem perdulário" (ANDRADE, 2009, p. 83), isto é, que não acumula, mas que (se) gasta, se transforma. Lembremos que a criação de tabus envolvida na introversão serviria "para uso exogâmico"; é através dela, segundo os antropófagos, "que partimos à aventura exterior da conquista (exogamia)", como se os tabus fossem aqueles "sinais" nos quais, segundo o Manifesto, devemos acreditar, que formam os "Roteiros" da "humana aventura". Zonas de perigo, sem dúvida, mas também de aventuras, de acontecimentos que comportam a experiência da transformação, da contaminação: o que contagia no contato com uma potência exterior com a diferença não é a identidade do outro, mas a sua diferença, a sua condição de exterioridade, o que leva o sujeito a sair de si, a se metamorfosear. Pois assim como a introversão leva à exogamia, essa, enquanto contato com uma exterioridade outra, demanda uma nova introversão, uma nova totemização, uma reconfiguração da experiência. Se a introversão, um dos aspectos da "conduta telepática", consiste em uma transformação do outro, do mundo (uma versão do mundo, uma dobra do mundo para dentro: intro-versão), a exogamia, o seu segundo aspecto, é uma transformação de si, uma saída de si, a aventura. Introversão e exogamia, dois processos inseparáveis de transformação (do outro e de si): comer é sempre uma via de mão dupla.

12. No "Informe sobre o modernismo", conferência proferida em 1945, Oswald, anunciando que "A Antropofagia ainda balbucia, mas propõe-se a depor no tumulto dramático de hoje" (ANDRADE, 2011b: pp. 155, 153-4), fornece ainda outra forma de expressar a oposição entre totem e tabu: "Viver é totemizar ou violar o tabu. O outro lado da operação, a criação do tabu, isto é, da limitação, do metro, do nomos, da lei e em geral de toda a adversidade que nos encara, é dada à Antropofagia pelo inglês Eddington, recentemente morto, o qual em seu admirável estudo sobre o mundo físico situa-se no limiar da era atômica, com o problema essencial da transformação do mundo não métrico 
em mundo métrico". Ainda que apareça apenas tardiamente nos escritos de Oswald, a oposição entre o métrico e não-métrico possivelmente lhe fosse conhecida já na época vanguardista. Não só porque, num plano geral, as idéias do físico inglês Arthur Eddington, próximo a Einstein, estivessem muito difundidas entre a intelectualidade cosmopolita, mas também, mais especificamente, pelo fato de Flávio de Carvalho, enquanto "delegado antropófago" no IV Congresso Pan-Americano de Arquitetura (realizado no Rio de Janeiro em 1930), fazer uso da oposição em referência à transformação do tabu em totem. ${ }^{11}$ Mas no que consistiria tal oposição? Eddington (1925, p. 200) a elaborou exatamente para substituir o dualismo entre mundo espiritual e mundo material, propondo um monismo em que o mundo pode aparecer sob diferentes aspectos, dois lados de uma mesma moeda: "Eu arrisco dizer que a divisão do mundo externo em um mundo material e outro espiritual é superficial, e que a linha profunda de clivagem é entre os aspectos métricos e não-métricos do mundo". A questão de Eddington (1929, p. 105) era a definição do campo específico à ciência, o qual buscava remeter não ao material, real ou concreto, mas àquelas facetas do mundo abertas à medição, à quantificação: "o que a ciência busca não são entidades de alguma categoria específica, mas entidades com um aspecto métrico". Por isso, ele formulará novamente a oposição, em suas Gifford Lectures de 1927, remetendo, agora, a dois campos da experiência (termo central aos antropófagos): "A clivagem entre o domínio científico e o extra-científico da experiência não é uma clivagem entre o concreto e o transcendental, mas entre o métrico e o não-métrico". É importante sublinhar que Eddington (1929, p. 288) não fala em porções ou partes do mundo distintas (nem mesmo de mundos distintos), propondo a distinção métrico/não-métrico justamente para demarcar um

\footnotetext{
"1 "Em São Paulo, fundou-se há alguns anos a ideologia antropofágica, uma exaltação do homem biológico de Nietzsche, isto é, a ressurreição do homem primitivo, livre dos tabus ocidentais, apresentado sem a cultura feroz da nefasta filosofia escolástica. $\mathrm{O}$ homem como ele aparece na natureza, selvagem, com todos os seus desejos, toda a sua curiosidade intacta e não reprimida. O homem que totemiza o seu tabu, tirando dele o rendimento máximo. O homem que procura transformar o mundo não métrico no mundo métrico, criando novos tabus para novos rendimentos, incentivando o raciocínio em novas esferas. Esta idéia iniciada em São Paulo por Raul Bopp, Oswaldo Costa, Clóvis Gusmão, Oswald de Andrade e outros, com ramificações no Rio e outros estados, foi entusiasticamente recebida pelo filósofo Keyserling e o urbanista Le Corbusier, que viram nela um meio de progredir: uma possível felicidade longínqua. O homem antropofágico, quando despido de seus tabus, assemelha-se ao homem nu. A cidade do homem nu será sem dúvida uma habitação própria para o homem antropofágico. Lá ele poderá sublimar os seus desejos organizadamente" (CARVALHO, 2010, p. 24).
} 
outro tipo de divisão, que diz respeito ao modo de ver e lidar, isto é, experimentar o mundo - assim, por maior que seja o avanço da ciência, ela não esgotará (e nem pode fazê-lo) o não-métrico: "Desse ponto de vista, nós reconhecemos um mundo espiritual ao lado do mundo físico. Experiência - a saber, o eu cum ambiente - compreende mais do que pode ser abarcado pelo mundo físico, limitado como é a um complexo de símbolos métricos". Quase ao final do livro, o físico fornece um exemplo ilustrativo da oposição:

I am standing on the threshold about to enter a room. It is a complicated business. In the first place I must shove against an atmosphere pressing with a force of fourteen pounds on every square inch of my body. I must make sure of landing on a plank travelling at twenty miles a second round the sun-a fraction of a second too early or too late, the plank would be miles away. I must do this whilst hanging from a round planet head outward into space, and with a wind of aether blowing at no one knows how many miles a second through every interstice of my body. The plank has no solidity of substance. To step on it is like stepping on a swarm of flies. Shall I not slip through? No, if I make the venture one of the flies hits me and gives a boost up again; I fall again and am knocked upwards by another fly; and so on. I may hope that the net result will be that I remain about steady; but if unfortunately I should slip through the floor or be boosted too violently up to the ceiling, the occurrence would be, not a violation of the laws of Nature, but a rare coincidence. These are some of the minor difficulties. I ought really to look at the problem four-dimensionally as concerning the intersection of my world-line with that of the plank. Then again it is necessary to determine in which direction the entropy of the world is increasing in order to make sure that my passage over the threshold is an entrance, not an exit.

Verily, it is easier for a camel to pass through the eye of a needle than for a scientific man to pass through a door. And whether the door be barn door or church door it might be wiser that he should consent to be an ordinary man and walk in rather than wait till all the difficulties involved in a really scientific ingress are resolved. (EDDINGTON, 1929, p. 342)

"Quando se lê" esse trecho, afirma Walter Benjamin (1993, p. 104) após citá-lo em uma carta a Gershom Scholem datada de 1938, "acredita-se estar ouvindo Kafka": "Não conheço na literatura nenhuma passagem que mostre no mesmo grau o gesto de Kafka". E, de fato, é como se estivéssemos "Diante da lei", a parábola kafkiana: o métrico (a lei, seja ela científica ou jurídica) impede, justamente, de atravessar a porta que demarca a fronteira entre o dentro e o fora, de praticar a exogamia, de fazer contato. É o tabu. Como atravessar a porta, como transformar o métrico em não-métrico?

13. No Manifesto Antropófago, a fórmula que temos trabalhado nesse texto aparece de formas distintas. A primeira delas remete exatamente a esses dois domínios da lei, do métrico, a saber, o direito e a ciência: "Tínhamos a justiça codificação da vingança. A ciência codificação da Magia. Antropofagia. A transformação permanente do Tabu em 
totem.” A segunda, por sua vez, parece mais enigmática: "De William James a Voronoff. A transfiguração do Tabu em totem.” Se a menção a James é de certo modo compreensível, na medida em que, enquanto filósofo pragmatista, parece participar do movimento de "Crítica do Espírito" que vimos acima, a referência a Voronoff, famoso por seus experimentos de xenotransplante (de testículos de macacos em seres humanos, por exemplo), soa, à primeira vista, como um chiste. ${ }^{12} \mathrm{Se}$, porém, a levamos a sério, uma interpretação possível talvez resida em encará-la como a proposta de superação dos limites (tabu) entre espécies. Todavia, em nenhum momento os antropófagos falam em superar o tabu. ${ }^{13}$ Antes, é sempre uma transformação dele que se apregoa - e nesse caso, uma transfiguração. A Antropofagia oswaldiana não consiste numa progressão evolutiva e/ou acumulativa que visa transcender todo limite; ao contrário, é a metamorfose que ela apregoa - e são justamente essas passagens, esses limiares que, segundo Steiner, o tabu marca preferencialmente. Para usar a terminologia dos próprios canibais: a transformação do tabu em totem é uma mudança de Gestalt, uma reconfiguração das relações entre as partes. Desse modo, a diferença entre espécies não implicaria a impossibilidade de contato e interação ativas, ou seja, não implica que ela não possa produzir ativamente uma transformação ou possibilitar uma aliança. A referência a Voronoff, ademais, nos permite entender melhor a idéia de absorção direta do tabu e de "introversão objetiva". Pois o que significa incorporar objetivamente o limite, absorver diretamente o tabu? Incorporar o limite, como vimos, não é superá-lo, ultrapassá-lo, nem mesmo dissolvê-lo: é torná-lo parte do corpo, é dar corpo ao limite, incorporar a medida do outro, violando o ditame de pureza que impede o toque e o contato, isto é, convertendo o valor

\footnotetext{
12 Voronoff era objeto de pilhéria constante dos vanguardistas. Assim, por exemplo, Antonio Garrido, em "Filosofia de Antropófago", texto publicado na Revista, afirma: "Antes de Voronoff enxertar glândulas, já os selvagens comiam macacos". Cf. também o delicioso texto de Valdes (1929) sobre o encontro imaginário entre o cirurgião russo e Fausto.

13 Há passagens que parecem remeter a uma superação, a uma ampliação de si: "Somos transformadores de cosmo-energia mas em luta de crescimento. Simplesmente." Mas aqui, "crescimento" designa não acúmulo, mas modificação dentro dos quadros termodinâmicos do princípio da conservação da energia: "Mundo. Equação objeto - energia - objeto. O drama se desenvolve porque toda afirmação temporal é balizada por uma negação espacial". Daí "os momentos que são sínteses biológicas" (tempo-tese; espaço-antítese), e daí o aparelho telepático operar "Em simples função temporal - Digestiva": o horizonte da "Cabina Ptolomaica" não se amplia espacialmente, ele não transcende ou amplia os limites, o seu horizonte de pedrada, mas (se) transforma (digere) o espaço (o mundo) em experiência, exogamia - síntese, sempre incompleta, sempre do "momento".
} 
desfavorável, a negação, em um totem, um valor favorável, que pode ser mobilizado transformando-se também o transformador nesse mesmo gesto.

Aqui talvez dois exemplos, aparentemente distantes um do outro, nos auxiliem. O que é a poesia senão esse dar corpo a um limite externo, internalizá-lo objetivamente? A cesura do verso, o branco da página, os pixels do monitor: a poesia, em todas as suas formas, é uma experimentação de medidas que atinge o não-métrico (totem, valor favorável) por meio da introversão de uma métrica (tabu, valor desfavorável), a sua conversão em um modo. É a própria limitação da extensão, ou melhor, a absorção do limite, que permite a intensificação poética. Pensemos naquele procedimento tipicamente oswaldiano, em que uma frase feita, um clichê, um brocardo, um dito cristalizado, uma passagem clássica se transformam radicalmente por meio de uma intervenção quase imperceptível (mas por isso mesmo ainda mais evidente), uma espécie de incidente acidental ou acidente incidental: Tupi or not tupi. O exemplo máximo desse procedimento é o poema mínimo "amor // humor", sobre o qual Raul Antelo (2006, p. 27) argumenta:

Cabe ao mínimo realizar a máxima aspiração dos visionários - a posse contra a propriedade (...) Constata-se, assim, que o marco do texto mínimo (as condições que permitem a deriva paranomásica) funciona, alternada e simultaneamente, como condição de possibilidade da tradição utópica (esse oxímoron...), abrindo a historicidade dessa construção ao leque infinito dos mundos possíveis. Da fala mor, o mor lapso: o maior é o menor.

A obtenção do efeito máximo se dá pelo mínimo - a transfiguração do Tabu em totem é a tradução de um limite que impede o acesso ao não-métrico em um modo de experimentálo, de fazer contato com a exterioridade. A poesia se solidifica justamente quando a métrica se converte em um limite absoluto, quando ela impede todo acesso ao nãométrico. Não por acaso, ao tentar formalizar a "substância poética fabulosa" da Amazônia em seu Cobra Norato, Raul Bopp (2008, pp. 23, 22) precisou abandonar "as antigas formas poéticas":

Procurei restituir, em versos, impressões recolhidas em minhas andanças na região. Senti claramente o desgaste das antigas formas poéticas, de vibrações silábicas em uso. Elas foram sendo substituídas por maneiras de dizer mais simples, em novos moldes literários (...) Os moldes métricos fracionados serviam para dar expressão às coisas do universo clássico. Mas deformam ou são insuficientes para refletir com sensibilidade um mundo misterioso e obscuro em vivências pré- 
lógicas. Precisava-se, por isso, romper com as limitações da processualística do verso, ensaiar qualquer coisa em novas escolas de formas (à maneira da vida vegetal, espontânea), em linguagem solta, em moldes rítmicos diferentes.

A Antropofagia é sempre uma questão de métrica.

Outro exemplo possível de absorção do limite e sua conversão em valor favorável é aquilo que Pierre Clastres descreveu como a "sociedade contra o Estado". O gesto de Clastres não consistiu apenas em mostrar que a ausência de Estado entre os ameríndios, que aparecia aos olhos dos cronistas e da teoria política clássica enquanto falta (uma falta a ser suprida, justamente, pelo Estado), constituía um gesto deliberado, uma recusa deliberada. Para Clastres (2003, p. 61), o "princípio de uma autoridade exterior e criadora de sua própria legalidade", ou seja, o princípio do poder, do limite e da hierarquia políticos, era negado por meio de algo que podemos chamar de "introversão objetiva": a sociedade "primitiva” internaliza o Estado, na figura do chefe, para melhor "exorcizar aquilo que está destinado a matá-lo: o poder e o respeito ao poder" (2003, pp. 216).

14. "O lado não-métrico das coisas... se quiser, o sonho. Se a faina do homem sobre a terra é a redução do mundo não-métrico ao mundo métrico, isto é, a redução da natureza pela técnica, o mundo não-métrico ressurgirá adiante porque está no interior da própria natureza” (ANDRADE, 1974, p. 215). Lido hoje, esse trecho de um diálogo de Chão, segundo volume de Marco Zero, parece ser um chamado para que transformemos a catástrofe ambiental em curso, a adversidade (meta-)física máxima, em um novo modo de vida, que incorporemos o limite e totemizemos o tabu que nos ameaça a todos, para evitar que o não-métrico ressurja não como sonho, mas pesadelo. E talvez a própria Antropofagia, enquanto "reivindicação do espírito natural a que se poderia chamar o movimento do homem, paralelo ao movimento da terra”, aponte para uma possível forma de fazê-lo: "Da equação eu parte do Cosmos ao axioma Cosmos parte do eu. Subsistência. Conhecimento. Antropofagia.” A fórmula, propositalmente ambígua, joga com os dois sentidos de "parte", que pode ser lido como substantivo (um termo é elemento do outro) ou conjugação do verbo partir (um termo se inicia a partir do outro). O "axioma Cosmos parte do eu" implicaria, assim, não um narcisismo subjetivista, mas antes a inter-relação, a interdependência do mundo para com os eus que o sustentam: cada eu é responsável 
pelo mundo, cada eu é o mundo - e o mundo só se dá a partir de cada $e u$, depende de todo eu. E, não por acaso, Oswald associa o axioma à subsistência, que é, por assim dizer, o aspecto econômico da "sociedade contra o Estado": como mostrou Marshall Sahlins em um artigo clássico, as ditas economias de subsistência, longe de designarem modos de produção em que se trabalha sem parar para conseguir o mínimo, são, na verdade, economias de abundância, em que há, nas palavras de Clastres (2003, p. 213), uma "recusa de um excesso" de produção, e consequentemente de trabalho. O mínimo de trabalho para o máximo de ócio (termo tão caro a Oswald): dito de outro modo, o excesso da produção é convertido em um excesso improdutivo. ${ }^{14}$ De novo, o métrico (o trabalho) é introvertido e transformado como modo de acesso ao não-métrico.

E, com isso, voltamos ao nosso ponto de partida, a saber, a relação entre a oposição totem e tabu e a (o estado de) natureza. Na passagem citada do romance, Oswald associa o sonho (por extensão, a imaginação, a poesia, a utopia) à natureza, e a técnica a uma redução desta - a uma limitação do sonho, poderíamos dizer. Tal associação tem a ver com o fato dele não contrapor civilização e cultura de um lado, e natureza de outro, mas antes, a "técnica, que é civilização", de um lado, e "a vida natural, que é cultura" (ANDRADE, 2011a, p. 146), de outro. O estado de natureza canibal não designa, portanto, uma vida fora da cultura, uma vida totalmente determinada por leis inexoráveis (o que seria o mundo métrico). Pelo contrário, o homem natural dos antropófagos é aquele que pode "cevar a sua preguiça inata, mãe da fantasia, da invenção e do amor", regido não por um instinto de preservação, mas pelo "instinto lúdico", isto é, o lado totêmico do homem, seu aspecto não-métrico: “O 'ato gratuito' de Gide é a marca do antropófago que faz a sua declaração de direitos" (ANDRADE, 2011b, p. 448). Assim, se, em contraposição, o "homem civilizado", o homem regido pela técnica (pela redução do não-métrico ao métrico) é a "negação do próprio ser humano", então, ele é, por definição, o lado tabu (o

\footnotetext{
14 Pela ligação entre "subsistência" e "conhecimento" na passagem do Manifesto, cabe uma remissão a Alexius Meinong, mencionado, aliás em "antropofagia e cultura", quando Oswald fala da "revisão já clássica de Brentano que nos legou (...) a orientação para o Objeto. Meinong. Um passo". Na sua Teoria dos objetos, Meinong (1981) usa o termo "subsistência" para designar um campo ontológico, um campo do Quasisein (quase-ser) ou do Aussersein (ser-fora), distinto da existência, muito mais rico que o regido pelo "privilégio em favor do atual (real)": todos aqueles objetos, possíveis e impossíveis, que podem ser pensados, possuem uma objetividade, são subsistentes, possuem uma "pseudoexistenz", uma existência fictícia. Como se vê, na economia, no conhecimento e na arte, a subsistência designa uma riqueza que o real, a produção e o cânone jamais podem oferecer, tampouco capturar e limitar.
} 
valor desfavorável, oposto, o contra, a negação). O que está em jogo - e por isso a Antropofagia não é só uma teoria da cultura, mas também e ao mesmo tempo uma filosofia da natureza - é uma concepção não-normativa da natureza, isto é, uma concepção da natureza enquanto espaço da multiplicidade e do contato, em contraposição à civilização entendida como espaço da ipseidade e da compartimentação: "Contra o homem artificial - burro e cacete - o homem natural. Contra o animal que se veste, o animal que se enfeita". O homem natural não designa, assim, uma essência ou um estado primordial, mas, antes, aquilo que não se conforma a uma medida, o que se explicita na equação seguinte, feita em uma passagem na qual Oswald fala da Conquista da América: "o aparecimento do homem natural, isto é, de uma humanidade diferente da que era então conhecida" (ANDRADE, 2011b, p. 399; grifos nossos). Natureza é diferença. É verdade que, por vezes, como em A crise da filosofia messiânica, propõe-se um esquema evolucionista, de matizes hegelianas, com a dialética entre homem natural (tese) e homem civilizado (antítese), resultando no "homem natural tecnizado". Todavia, e como que relembrando a sua interpretação, no mínimo, peculiar da dialética hegeliana exposta na entrevista sobre a psicologia antropofágica, em que ela é concebida como uma “permanente e, graças a Hegel, insolúvel contradição”, Oswald encerra A crise justamente com uma hipótese que desmente toda possibilidade de síntese final: "Que o homem, como o vírus, o gen, a parcela mínima da vida, se realiza numa duplicidade antagônica benéfica, maléfica -, que traz em si o seu caráter conflitual com o mundo" (ANDRADE, 2011

15. Desse modo, devemos ver na "radical oposição de conceitos que dá uma radical oposição de conduta" não uma oposição temporal, como em Totem e tabu, mas duas linhas de força, dois "hemisférios culturais", ou melhor, pólos culturais, para os quais são atraídos mais ou menos as sociedades e os indivíduos humanos. De um lado, a "cultura antropofágica”, de outro, a “cultura messiânica”, para a qual a Terra é exterior ao homem e o contato (contagiante) com ela deve ser evitado: "as civilizações que admitem uma concepção messiânica da vida, fazendo o indivíduo objeto de graça, de eleição, de imortalidade e de sobrevivência, se dessolidarizam, produzindo o egotismo do mundo 
contemporâneo. Para elas, há a transcendência do perigo e sua dirimição em Deus” (ANDRADE, 2011a, p. 219). Para Oswald, a transcendência do perigo se daria justamente pela promessa da vida extra-terrena (o messianismo religioso), ou então, de um futuro de felicidade (messianismo político) - ao que poderíamos acrescentar uma terceira forma, o messianismo técnico, a que Oswald mesmo de certa forma aderiu, em que todo perigo, incluindo a morte (individual ou da espécie), pode ser transcendido pela tecnologia, como se fosse possível nos libertarmos da nossa "Cabina Ptolomaica", "presa às convicções horizontais e estáticas da terra”. E, paradoxalmente, a transcendência do perigo se dá na forma da metrificação total, pela contenção do perigo (as prisões, os manicômios, mas também a individuação de um gene nocivo, por exemplo), a busca justamente de um Absoluto, de um indivíduo, a fronteira final. Por seu turno, a cultura antropofágica "Compreende a vida como devoração e a simboliza no rito antropofágico, que é comunhão. De outro lado a devoração traz em si a imanência do perigo. E produz a solidariedade social que se define em alteridade", isto é, "ao sentimento do outro, (...) de ver o outro em si, de constatar-se em si o desastre, a mortificação ou a alegria do outro" (ANDRADE, 2011a, p. 219-220). Sociedades existencialmente endogâmicas, por um lado, sociedades existencialmente exogâmicas de outro, sociedades que evitam o perigo e sociedades que o encaram..$^{15} \mathrm{~A}$ imanência do perigo implica, assim, a imanência do tabu, a “imanência do inimigo" (VIVEIROS DE CASTRO, 2002, pp. 267-294). E talvez o inimigo hoje sejamos nós mesmos, humanos demasiadamente humanos, por demais extraterrestres, por demais crentes na possibilidade de transcender o perigo, a catástrofe ambiental. Como, enfim, tornar o perigo imanente?

16. A resposta de Oswald será "Virar índio" (2007, pp. 200-1). Talvez o melhor exemplo de transformação do métrico em não-métrico seja a própria Antropofagia de Oswald e seus companheiros: postular o índio como "a chave que o mundo cegamente procura"

15 Em Tristes Trópicos, Lévi-Strauss (2005, p. 366) traça uma diferenciação muito semelhante a oswaldiana, entre sociedades "que praticam a antropofagia, isto é, que enxergam na absorção de certos indivíduos detentores de forças tremendas o único meio de neutralizá-las, e até de se beneficiarem delas; e as que, como a nossa, adotam o que se poderia chamar de antropoemia (do grego emein, 'vomitar'). Colocadas diante do mesmo problema, elas escolheram a solução inversa, que consiste em expulsar esses seres tremendos para fora do corpo social, mantendo-os temporária ou definitivamente isolados, sem contato com a humanidade, em estabelecimentos destinados a este fim." 
(ANDRADE, 2008, p. 79). Mas - e isso é essencial - essa chave não fecha portas, ela só as abre: aquilo que os antropófagos chamavam de "índio" não designava um modo de vida específico e individualizável (quanto menos, como era costume à época, uma raça ou um estado primitivo), ou seja, uma medida fixa, mas justamente a possibilidade de transformar toda medida, de convertê-la em acesso a algo outro (virar do avesso, introverter, inverter), a algo fora da medida: o antropófago, i.e., aquele que transforma o tabu em totem, aquele que sabe que não há vida sem diferença, que sabe o que comer, que saber que precisa comer para viver. Assim, Bopp (2008, p. 108) utilizará uma imagem métrica para caracterizar a operação antropofágica: "Estamos recrutando fatores postos à margem. Forças escondidas. Mal apalpadas. Que ainda não couberam no sistema métrico ocidental. Î́ndio". Mas o índio não caberia no "sistema métrico ocidental" porque indica antes de tudo uma "força", e não uma forma. Por isso, em um texto assinado por Cunhambebinho, o "grande sentido aventureiro", ou seja, o sentido que leva à exogamia, ao contato, a um sair de si, é definido como o sentido "índio do homem". Entretanto, a exogamia, o sair de si, o diferir ou devir-outro, não é uma possibilidade dada metafisicamente ao homem, mas depende da experiência (o monismo canibal), do contato direto com a diferença (pra haver transformação é preciso a alteridade, pra metamorfosear-se no outro, é preciso que haja um outro). Retomemos o que Oswald chamou de "o aparecimento do homem natural, isto é, de uma humanidade diferente da que era então conhecida". Os efeitos do contato entre o europeu e o homem nu dos trópicos, para Oswald, abarcaram desde o florescimento do humanismo até (o que nos interessa mais de perto) o que ele chamava de "A marcha das Utopias": "As Utopias são (...) uma conseqüência da descoberta do novo homem, do homem diferente encontrado nas terras da América" (ANDRADE, 2011a, p. 224). O contato com uma humanidade diferente mostrou a contingência das formas civilizacionais existentes, e a possibilidade de imaginar novas: as utopias seriam, desse modo, a transformação de um tabu, um valor oposto (o primitivo) em um totem, um valor favorável de acesso ao não-métrico, de algo que estava fora da medida. A ida ao homem natural designa justamente esse processo de "desdomestificação" (para usar um termo de Oswald): "O que se quer é a simplicidade e não um novo código de simplicidade. Naturalidade. Não manuais de bons tons". Ou seja, 
e observe-se a sinonímia que Oswald traça entre novo, natural e diferente, o que possibilitou a imaginação de novas configurações políticas no mundo ocidental (e mesmo sua concretização, pois "Sem nós a Europa não teria sequer sua pobre declaração dos direitos do homem") foi justamente o encontro concreto com a diferença.

Em uma belíssima definição, Oswald afirmou que "O índio (...) é mais do que tudo o desenvolvimento de um estado de luta que a memória desperta" (ANDRADE, 2009, p. 8o). Aqui se encontram tanto a dimensão "genérica" do índio (o "estado de luta": o índio como sentido aventureiro do homem, como possibilidade de sair da medida), quanto a concreta, pois é a "memória" (a memória da luta do índio) que "desperta" essa luta contra a medida: "Com toda a coação e a libidinagem da gente branca, não foi, no entanto, destruído o que melhor restava no natural das Américas. A sua cultura resistiu no fundo das florestas, como na recusa a toda força escravizante." No fundo das florestas assim como na recusa a força escravizante: nunca um sem o outro, pois "Toda a literatura, mesmo a missionária, que no século XVI encheu de novidade o mundo, aqui permaneceu para escândalo do mundo vestido e algemado que nos traziam". Sem o contato direto com os índios não seria (e não será) possível “virar índio". É por isso que "Só o selvagem nos salvará. Essa força profunda que sentimos e que cumpre conservar nos veio dele." Se, à época de Oswald, a Antropofagia podia ser definida como "o gérmen da mentalidade que irá combater na segunda guerra contra os emboabas de outros tempos, transformados agora em ideias, despidos da contingência física e, assim, mais nocivos e fortes", atualmente presenciamos uma terceira guerra, em que os "emboabas", sem deixarem de ser idéias, tomam corpo novamente. $\mathrm{O}$ atual ataque aos índios brasileiros por parte de governantes, elites econômicas, mídia e parcelas da sociedade civil, ataque que Viveiros de Castro (2013) chamou de "ofensiva final contra os povos indígenas", não se dá, portanto, apenas contra os povos indígenas (como se isso não bastasse), mas, ao mesmo tempo e conjuntamente, à possibilidade, inscrita em cada um desses que chamamos de humanos, de virar índio, de sair dessa medida humana, de transformá-la em algo diferente do que aquela espécie que caminha a passos largos para acabar com toda a diferença, toda a vida, inclusive a própria, na Terra. 
17. É provável (ou, ao menos, possível) que Oswald tivesse em mente um aspecto específico do ritual antropofágico ameríndio ao associá-lo a isso que chamava de transformação do tabu em totem. Seguidamente, ele insistiu que a antropofagia ritual não era movida por questões de "substância": não se comia o inimigo "por gula ou por fome" (ANDRADE, 2011a, p. 138). Antes, Oswald sublinhava o seu caráter "mágico", "religioso", ou "simbólico", que "dá a idéia de exprimir um modo de pensar, uma visão de mundo". Por outro lado, ele poucas vezes, ao contrário do que o senso comum apregoa, relacionou o canibalismo à absorção de qualidades do devorado. O que, então, sobra? Sobra - o que não é pouco - o nome: "O ser comido batizava o que comia. $\mathrm{O}$ índio adotava o nome daquele comera, por julgá-lo superior, já intelectualmente, já moralmente" (ANDRADE, 2009, p. 66). Embora os relatos sobre a antropofagia tupi sejam contraditórios, em grande parte deles encontramos uma relação entre a devoração do inimigo (ou ao menos, o ato de rachar o crânio do inimigo a ele coligado, relação que não passou desapercebia pelos antropófagos: "O nosso troféu clássico: o crânio do inimigo", lemos num texto da Revista) e a modificação (ou multiplicação) de nome por parte do devorador/matador (se o inimigo não fornecia o próprio nome, a sua morte ou devoração era, enquanto rito de passagem, condição de possibilidade de adquirir um novo nome). Existe algo que marque mais uma alteridade, uma diferença, um limite, que o nome do outro (o Nomos do outro)? E a absorção dele não implica, assim, a transformação do tabu em totem, a conversão de uma divisão métrica em um acesso a um fora, a uma outra perspectiva (inclusive sobre si mesmo: exogamia), a uma identificação com uma exterioridade?

Possivelmente os inimigos mais visíveis e visados da atual guerra movida em nosso (?) país contra os índios sejam os Guarani-Kaiowá. Em reação, milhares, talvez milhões, disseram, nas ruas e nas redes sociais: "Sou Guarani-Kaiowá", adotando simbolicamente o etnônimo como sobrenome, como nome da família. Exogamia. Rapidamente, pois a ofensiva tem várias frentes, a fórmula proliferou, se desdobrou, se multiplicou: sou Guarani-Kaiowá, mas sou também Munduruku (em luta pelo direito à consulta prévia), como também Kayapó (povo que resiste há décadas à implantação desse monumento ao desastre, à barragem dos fluxos vitais, que é a usina de Belo Monte), e me identifico também com os Tupinambá e com tantos povos quanto forem aqueles que detêm direitos 
originários mas são diariamente removidos ou ameaçados de remoção pela especulação imobiliária ou por disputas fundiárias, etc. A partir disso, em um gesto ímpar na história literária, André Vallias (2014) escreveu um poema composto pelos etnônimos de 222 povos indígenas, com cada 6 ou 7 estrofes iniciando por "Sou”, a começar, evidentemente, com "Sou Guarani-Kaiowá". Desse modo, Vallias converteu uma forma, a nomeação e identificação proliferante, justamente em um modo: virar-índio é abrir-se à multiplicidade. Na medida em que não esgota (nem visa fazê-lo) os nomes dos povos indígenas "registrados", o poema está sempre incompleto, sempre aberto à diferença, abarcando, no horizonte, outros nomes, mesmo aqueles que não conhecemos, daqueles que chamamos apenas de "brabos" (como se sua resistência dissesse respeito até mesmo à nomeação pelos outros), e também os nomes não-indígenas, pois subsistem nele potencialmente todos os inimigos declarados e não declarados de uma guerra tanto real quanto imaginária promovida pelo Estado brasileiro. Pois o poema não enumera vítimas, mas elenca aliados, e, mais do que isso, afirma uma oposição de procedimentos, de modos de pensar, de visões de mundo, entre, por um lado, a multiplicidade, a metamorfose, a exogamia, e, por outro, a intocabilidade, o absoluto. Por isso, o poema é um contra-hino de nossos tempos (o contrário do hino platônico enquanto elegia estatal e dos heróis da pátria, única forma poética admitida na República ideal). E por isso ele se chama justamente Totem. Nele, a multiplicidade, a "heteronímia canibal", se apresenta como um verdadeiro grito de guerra contra a unidade daquele que Vallias não nomeia nem pode nomear: o Humano, o nosso tabu. Os humanos podem ser muitos, mas nós somos múltiplos. "Nós, os outros. Nósoutros. Nosoutros" ${ }^{16}$ Antropófagos.

\section{Referências}

AGAMBEN, Giorgio. Homo sacer I: o poder soberano e a vida nua. Tradução de Henrique Burigo. Belo Horizonte: Editora da UFMG, 2002.

ANDRADE, Oswald de. A utopia antropofágica. 4. ed. São Paulo: Globo, 2011.

16 Cf. o texto "Totemsemia”, publicado na Atual, n.2:

http://issuu.com/oultimojornaldaterra/docs/atual_2_2013 
. Os dentes do dragão: entrevistas. Organização, introdução e notas de Maria Eugenia Boaventura. 2. ed. revista e ampliada. São Paulo: Globo, 2009.

_. Telefonema. Organização, introdução e notas de Vera Maria Chalmers. 2. ed., aumentada. São Paulo: Globo, 2007.

_.. Um homem sem profissão. Memórias e confissões. Sob as ordens da mamãe. 2. ed. São Paulo: Globo, 2002.

_. Estética e política. Organização, introdução e notas de Maria Eugenia Boaventura. 2. ed., revista e ampliada. São Paulo: Globo, 2011 b.

_.. Marco Zero 2: Chão. (Obras completas Vol. IV). 2.ed Rio de Janeiro: Civilização

Brasileira, 1974 .

ANTELO, Raul. “Quadro e caderno”. Em: ANDRADE, Oswald. Primeiro caderno do aluno de poesia Oswald de Andrade. 4. ed., revista. São Paulo: Globo, 2006.

BENJAMIN, Walter. Carta a Gershom Scholem. Novos estudos, v. 35 (1993). pp. 100-106.

BOPP, Raul. Vida e morte da antropofagia. 2. ed. Rio de Janeiro: José Olympio, 2008.

CANETTI, Elias. Massa e poder. Tradução de Sérgio Tellaroli. São Paulo: Companhia das Letras, 1995.

CARVALHO, Flávio de. A origem animal de Deus. O bailado do Deus morto. São Paulo: Difusão Européia do Livro, 1973.

__. "A cidade do homem nu”. Em: Catálogo da exposição "A cidade do homem nu”. São Paulo: MAM, 2010.

CERA, Flávia; NODARI, Alexandre. A horda zumbi. Rastros, n. 6 (2013). pp. 1-4.

CLASTRES, Pierre. A sociedade contra o Estado. Tradução de Theo Santiago. São Paulo: Cosac Naify, 2003. 
EDDINGTON, Arthur S. "The domain of physical science”. Em: NEEDHAM, Joseph (ed.). Science, Religion and Reality. Nova Iorque: The Macmillan Company, 1925. pp. 187-218. . The nature of the physical world. Nova lorque: The Macmillan Company, 1929.

FREUD, Sigmund. Obras completas, v. 11 (1912-1914): Totem e Tabu, contribuição à história do movimento psicanalítico e outros textos. Tradução e notas de Paulo César de Souza. São Paulo: Companhia das Letras, 2012.

_. O futuro de uma ilusão. Tradução de Renato Zwick. Porto Alegre: L\&PM, $2010 a$. . Obras completas, v. 16 (1923-1925): O eu e o id, "Autobiografia" e outros textos. Tradução e notas de Paulo César de Souza. São Paulo: Companhia das Letras, 2011. _. Obras completas, v. 14 (1917-1920): História de uma neurose infantil ("O homem dos lobos", Além do princípio do prazer e outros textos. Tradução e notas de Paulo César de Souza. São Paulo: Companhia das Letras, 2o1ob.

KOFFKA, Kurt. Perception: An introduction to the Gestalt-Theorie. Psychological Bulletin, v. 19 (1922). pp. 531-585.

_. Principles of Gestalt psychology. Nova Iorque: Harcourt, Brace and Company, 1936. . The growth of mind. Nova Iorque: Harcourt, Brace and Company, 1924.

KÖHLER, Wolfgang. Gestalt Psychology. Nova Iorque: Horace Liveright, 1929.

LEVI-STRAUSS, Claude. Tristes trópicos. 6. reimpressão. Tradução de Rosa Freira D’Aguiar. São Paulo: Companhia das Letras, 2005.

MARQUES, Pedro Neves. The Forest and the School. How to sit at the dinner table? Berlim: Archive Books, 2014.

MEINONG, Alexius. "Theory of objects”. Em: CHISHOLM, Roderick (ed.). Realism and the Background of Phenomenology. Atascadero: Ridgeview, 1981. pp. 76-117. 
MELVILLE, Herman. Typee: a peep at Polynesian life. Part I. Nova Iorque: Wiley and Putnam, 1846.

MILLER, Arthur I. Albert Einstein and Max Wertheimer: A Gestalt psychologist's view of the genesis of special relativity theory. History of science: an annual review of literature, research and teaching, v. 13 (1975). pp. 75-103.

NODARI, Alexandre. O extra-terrestre e o extra-humano: notas sobre a revolta kósmica da criatura contra o criador. Landa, v. 1, n. 2 (2013). pp. 251-261.

Revista de Antropofagia: $1^{\underline{a}}$ e $2^{\underline{a}}$ dentições. (fac-símile). São Paulo: Abril, Metal Leve, 1975.

STEINER, Franz. Taboo. 2. ed. Londres: Penguin Books, 1967.

VALDÉS, Ildefonso Pereda. Elogio de Voronoff. Verde, v. 1 (1929). p. 10.

VALLIAS, André. Totem. Introdução (trilíngue: português/inglês/guarani-kaiowá). Meiembipe (Florianópolis): Cultura e Barbárie, 2014.

VIVEIROS DE CASTRO, Eduardo. A inconstância da alma selvagem e outros ensaios de antropologia. São Paulo: Cosac Naify, 2002.

. Últimas notícias sobre o fim do mundo. III Conferência Curt Nimuendajú. São Paulo: CESTA/USP, 2013. Disponível em http://vimeo.com/81488754 